\title{
OCCURRENCE OF LOPHODERMIUM SPP. IN YOUNG SCOTS PINE STANDS IN LATVIA
}

\author{
Kaspars Polmanis ${ }^{1,2}$, Talis Gaitnieks' ${ }^{1}$, Viktorija Beḷeviča ${ }^{1}$, Dainis Rungis ${ }^{1}$, Anita Baumane ${ }^{1}$ \\ ${ }^{1}$ Latvian State Forest Research Institute 'Silava' \\ ${ }^{2}$ Latvia University of Agriculture \\ kaspars.polmanis@silava.lv
}

\begin{abstract}
Scots pine (Pinus sylvestris L.) is one of the most widespread coniferous species in boreal zones and it has a considerable economic importance in the Baltic countries. The impact of fungi on Scots pine has been known also historically, but it is predicted that it will increase in future due to climate changes that will have a positive effect on incidence and vitality of various species of fungi. The aim of the study was to characterize the occurrence of Lophodermium spp. in young stands of Scots pine in Latvia. Needle samples were collected from young pine stands (aged $1-14$ years) located in all regions of Latvia. DNA extraction from needles was done using modified CTAB protocol, presence of Lophodermium in total extracted DNA was detected using a PCR method. Meteorological data - air temperature and precipitation - were obtained from all 34 observation stations of the Latvian Environment, Geology and Meteorology Centre. The presence of Lophodermium spp. was detected in all surveyed stands, and occurrence differences between the western and eastern regions were significant $(\mathrm{p}=0.004)$. The occurrence of Lophodermium spp. in the eastern and western regions was affected by the meteorological conditions in autumn and winter of the previous years, as well as differences in the given years' air temperature and precipitation. In 2016, the eastern region of Latvia had a higher May-August precipitation and, to a lesser extent, temperature, which correlated with a higher occurrence of Lophodermium spp.
\end{abstract}

Key words: needle cast, disease distribution, meteorological conditions.

\section{Introduction}

Pine forests have considerable economic importance in the Baltic countries, as demonstrated both by the contribution of the forestry sector to the Gross Domestic Product (GDP) and the proportion of wood and wood products in total export value. Therefore, it is important to understand threats that might negatively affect vitality and growth of Scots pine trees in Latvia. Many threats are associated with rapidly progressing climate changes (Edenhofer et al., 2014). The relationship between meteorological factors and increment (both height and radial) of Scots pine has been well studied and the obtained results mainly demonstrate a slightly positive influence of the predicted changes on tree growth (Jansons et al., 2013a, 2013b, 2015a, 2016a; Rieksts-Riekstins et al., 2014). One of the threats to young Scots pine trees in particular is a needlecast disease caused by fungus Lophodermium seditiosum. Lophodermium spp. are highly diverse endophytic fungi with woody hosts, representing a range of symbiotic interactions with their host plants, from commensals and mutualists to latent pathogens. They have a one-year development cycle (Ortiz-García et al., 2003). Lophodermium seditiosum is one of the most important pathogens of Scots pine (Pinus sylvestris L.) needles in nurseries and young stands (Drenkhan, 2011). If the infection of this fungus in the forest nursery is not resolved, it can spread to young pine stands (Klavina et al., 2012). Therefore, research has been done to develop effective fungicides to combat the disease (Millar, 1975; Ormrod, 1976). Weather conditions favorable for this disease are increasingly observed during recent decades - humid and warm autumns (as well as the end of summer) and mild winters (Martinsson, 1979; Diwani \& Millar, 1990; Stenström \& Arvidsson, 2001), making this period of time suitable for the studies of occurrence and impact of this disease. Hanso \& Drenkhan (2007) indicate that Estonian climatic conditions (cold winters) are not an obstacle to the spread of the disease, which are favorable in late summer and autumn. Host-pathogen co-evolution as well as tree breeding had ensured development of resistance of local Scots pine individuals (genotypes) against the disease (Reich et al., 2003; Booy et al., 2000).

In recent years, other diseases significantly affecting needles have also been identified in Latvia: Diplodia pinea (Desmo.) J. Kickx and Dothistroma septosporum (Dorogin) M. Morelet (Adamson et al., 2015). The occurrence of new pathogens as well as increased influence of the already present ones is expected in future. Change of dominant tree species is a feasible option only in limited areas (Jansons et al., 2016b) due to specific soil requirements and economic importance of Scots pine. Tree breeding (and use of selected material in forest regeneration) can have an important role in reduction of the $L$. seditiosum and other needlecast diseases, since it is well developed and financially viable activity in Latvia (Jansons et al., 2015b) with proven effects on quantitative traits of Scots pine (Jansons, 2008; Jansons et al., 2006). Therefore, the existing breeding and propagation opportunities such as experimental 
trials, infrastructure, as well as seed orchards, can be used to improve the resistance of needlecast simultaneously with other traits. Earlier studies had indicated the potential role of genetics in resistance to the needlecast (Liesebach \& Stephan, 1996), but this effect may vary between the populations within a species. The aim of the study was to characterize the occurrence of Lophodermium spp. in young Scots pine stands in Latvia, and to investigate the correlation with meteorological factors.

\section{Materials and Methods}

Twelve young stands of Scots pine (further in the text 'objects') (Table 1) were selected -5 stands in Western (W) Latvia, 5 stands in Eastern (E) Latvia and two stands in the central (C) part of Latvia. A report describing the presence of Lophodermium spp. in Scots pine stands in Latvia (Moročko-Bičevska et al., 2010), was utilized to select the sampling locations. In each stand the needle samples from 24 trees (aged $1-14$ years) were collected. The total surveyed area of young stands was 20.7 ha (Fig. 1). The analyzed stands were located up to $1 \mathrm{~km}$ from the young stands that were surveyed in 2009 and had similar tree dimensions and growth conditions (mineral soil, surrounded by other Scots pine stands). Location of young stands was determined by GARMIN eTrex 20 navigator.

In each young stand along the longest diagonal, $6-15$ needles of the previous year damaged by Lophodermium spp. were collected from 24 trees and inserted in sealable plastic bags. Needle samples were collected in August. Accurate monthly average values of air temperature $\left({ }^{\circ} \mathrm{C}\right)$, precipitation $(\mathrm{mm})$ and relative air humidity (\%) for the selected study objects in years - 2008, 2009, 2015 and 2016 were obtained by spline interpolation. With spline interpolation method the image raster cells whose dimensions were $100 \times 100 \mathrm{~m}$ in nature were created, reflecting accurate weather data information about the above-mentioned areas. Meteorological data - air temperature and precipitation in 2008, 2009, 2015 and 2016 - were obtained from all 34 observation stations of the Latvian Environment, Geology and Meteorology Centre.

In total, 288 samples were collected in 2016 from all regions of Latvia. Both objects from the central part of Latvia were excluded from further analysis to sufficiently differentiate the western and eastern regions. Consequently, results from only 240 needle samples were used for further mathematical analysis. DNA extraction from all samples was done using modified CTAB (Doyle \& Doyle, 1987) protocol. Presence of Lophodermium in total extracted DNA was detected using a PCR method as described previously (Stenström \& Ihrmark, 2005).

Descriptive statistics was used to characterize the data; chi-square criterion was used to analyze differences between the occurrence of Lophodermium spp. infection in the western and eastern regions and differences in infection frequency between years in these regions (Arhipova \& Balina, 2003).

\section{Location and inventory parameters of studied objects}

Table 1

\begin{tabular}{|c|c|c|c|c|c|c|c|c|}
\hline \multirow{2}{*}{$\begin{array}{c}\text { Object } \\
\text { No. }\end{array}$} & \multirow{2}{*}{ Regions } & \multicolumn{2}{|c|}{ Object location } & \multirow{2}{*}{$\begin{array}{c}\text { Stand } \\
\text { area, } \\
\text { ha }\end{array}$} & \multirow{2}{*}{$\begin{array}{l}\text { Stand } \\
\text { age, } \\
\text { years }\end{array}$} & \multirow{2}{*}{$\begin{array}{c}\text { Stand } \\
\text { average } \\
\text { H, m }\end{array}$} & \multirow{2}{*}{$\begin{array}{c}\text { Stand } \\
\text { average } \\
\text { DBH, cm }\end{array}$} & \multirow{2}{*}{$\begin{array}{c}\text { Stand } \\
\text { density, } \\
\text { trees ha }\end{array}$} \\
\hline & & Latitude & Longitude & & & & & \\
\hline 1 & Western & $56^{\circ} 40^{\prime} 30.13^{\prime \prime} \mathrm{N}$ & $22^{\circ} 16^{\prime} 42.30^{\prime \prime} \mathrm{E}$ & 3.6 & 6 & 1.9 & $3.5^{*}$ & 3100 \\
\hline 2 & Western & $57^{\circ} 2 ’ 15.66^{\prime \prime} \mathrm{N}$ & $23^{\circ} 10^{\prime} 20.08^{\prime \prime} \mathrm{E}$ & 1.6 & 7 & 3.2 & $5.2 *$ & 3200 \\
\hline 3 & Western & $57^{\circ} 27^{\prime} 44.09 ” \mathrm{~N}$ & $22^{\circ} 40^{\prime} 47.95^{\prime \prime} \mathrm{E}$ & 1.0 & 10 & 4.8 & $5.8^{*}$ & 2800 \\
\hline 4 & Western & $57^{\circ} 20^{\prime} 59.24 ” \mathrm{~N}$ & $22^{\circ}$ 6'14.71’"E & 0.7 & 12 & 9.2 & $9.5^{*}$ & 2500 \\
\hline 5 & Western & $57^{\circ} 3{ }^{\prime} 41.59^{\prime \prime} \mathrm{N}$ & $21^{\circ} 48^{\prime} 44.67^{\prime \prime} \mathrm{E}$ & 0.7 & 4 & 1.5 & $2.7^{*}$ & 3350 \\
\hline 6 & Eastern & $56^{\circ} 36^{\prime} 8.05^{\prime \prime} \mathrm{N}$ & $25^{\circ} 35^{\prime} 5.24$ ”'E & 0.7 & 6 & 2.2 & $3.7 *$ & 2700 \\
\hline 7 & Eastern & $56^{\circ} 48^{\prime} 41.10^{\prime \prime} \mathrm{N}$ & $26^{\circ} 7{ }^{\prime} 46.21$ ”E & 2.7 & 4 & 0.9 & $1.8^{* *}$ & 3300 \\
\hline 8 & Eastern & $56^{\circ} 34^{\prime} 43.14^{\prime \prime} \mathrm{N}$ & $26^{\circ} 40^{\prime} 28.90^{\prime \prime} \mathrm{E}$ & 0.7 & 3 & 1.1 & $2.1 * *$ & 3250 \\
\hline 9 & Eastern & $56^{\circ} 27^{\prime} 11.62 ” \mathrm{~N}$ & $27^{\circ} 17^{\prime} 20.52$ 'Е & 0.5 & 10 & 6.5 & $6.2^{*}$ & 1900 \\
\hline 10 & Eastern & $56^{\circ} 5{ }^{\prime} 28.54 ” \mathrm{~N}$ & $26^{\circ} 21^{\prime} 42.05^{\prime \prime} \mathrm{E}$ & 2.8 & 5 & 2.1 & $2.9^{*}$ & 3400 \\
\hline 11 & Central & $56^{\circ} 43^{\prime} 12.75^{\prime \prime} \mathrm{N}$ & $23^{\circ} 41^{\prime} 9.75^{\prime \prime} \mathrm{E}$ & 1.3 & 11 & 8.9 & $9.3^{*}$ & 2200 \\
\hline 12 & Central & $56^{\circ} 55^{\prime} 55.09 " \mathrm{~N}$ & $24^{\circ} 23^{\prime} 23.74^{\prime \prime} \mathrm{E}$ & 4.4 & 3 & 0.9 & $1.9^{* *}$ & 2900 \\
\hline
\end{tabular}

*DBH - mean diameter at breast height; ** mean diameter at root collar; $\mathrm{H}$ - mean height. 


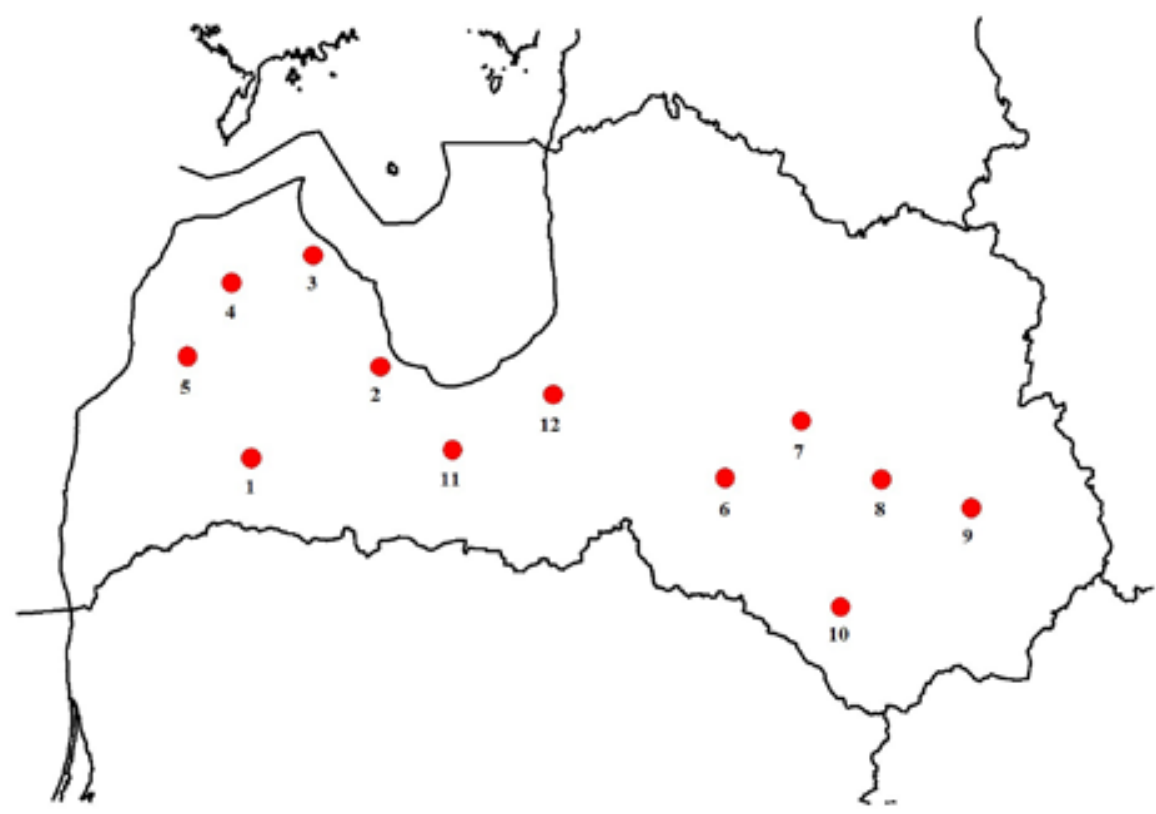

Figure 1. The location of research objects.

\section{Results and Discussion}

Correlations were not found between the young stand height, diameter and density indicators and their impact on Lophodermium spp. Therefore, data were further analyzed as a single set of data, evaluating them between years. The study shows that Lophodermium spp. were present in needles collected from all analyzed objects. This correlates with results from a previous report, where Lophodermium spp. were present in similar localities (Moročko-Bičevska et al., 2010).

The proportion of individuals where Lophodermium spp. were detected using a PCR method ranged from $50.0 \%$ (Stand 4) up to $100 \%$ (Stands 7, 8,

Detection of Lophodermium spp. and meteorological data at each object

\begin{tabular}{|c|c|c|c|c|c|c|c|c|c|c|}
\hline \multirow[t]{2}{*}{$\begin{array}{c}\text { Object } \\
\text { No. }\end{array}$} & \multirow[t]{2}{*}{ Region } & \multirow[t]{2}{*}{$\begin{array}{l}\text { Lophodermium } \\
\text { spp. detection, \% } \\
\text { in } 2016\end{array}$} & \multicolumn{2}{|c|}{$\begin{array}{c}\text { Average autumn } \\
\text { precipitation, } \\
\text { mm }\end{array}$} & \multicolumn{2}{|c|}{$\begin{array}{c}\text { Average winter } \\
\text { temperatures, } \\
{ }^{\circ} \mathrm{C}\end{array}$} & \multicolumn{2}{|c|}{$\begin{array}{c}\text { Average } \\
\text { temperature } \\
\text { from May to } \\
\text { August, }{ }^{\circ} \mathrm{C}\end{array}$} & \multicolumn{2}{|c|}{$\begin{array}{c}\text { Average } \\
\text { precipitation } \\
\text { from May to } \\
\text { August, mm }\end{array}$} \\
\hline & & & 2008 & 2015 & 2008 & 2015 & 2009 & 2016 & 2009 & 2016 \\
\hline 1 & Western & 83.3 & 206.0 & 235.0 & -2.0 & -0.7 & 14.6 & 15.8 & 282.2 & 317.7 \\
\hline 2 & Western & 87.5 & 166.8 & 199.3 & -1.2 & -0.2 & 15.0 & 16.3 & 307.2 & 357.3 \\
\hline 3 & Western & 87.5 & 207.2 & 190.4 & -1.1 & -0.1 & 14.2 & 15.4 & 386.0 & 360.0 \\
\hline 4 & Western & 50.0 & 260.0 & 228.6 & -1.4 & -0.3 & 14.3 & 15.2 & 328.7 & 315.9 \\
\hline 5 & Western & 95.8 & 300.8 & 253.5 & -1.5 & -0.3 & 14.2 & 15.9 & 282.2 & 279.1 \\
\hline \multicolumn{2}{|c|}{ Average western } & 80.8 & 228.1 & 221.4 & -1.4 & -0.3 & 14.5 & 15.7 & 317.3 & 326.0 \\
\hline 6 & Eastern & 79.2 & 206.9 & 233.8 & -2.9 & -2 & 14.7 & 16.4 & 315.7 & 425.4 \\
\hline 7 & Eastern & 100 & 199.0 & 174.9 & -3.3 & -2.5 & 14.4 & 16.1 & 308.4 & 341.5 \\
\hline 8 & Eastern & 100 & 176.3 & 241.4 & -3.1 & -2.4 & 14.8 & 16.4 & 294.2 & 320.3 \\
\hline 9 & Eastern & 87.5 & 175.7 & 285.0 & -3.5 & -2.4 & 14.4 & 16.2 & 334.0 & 291.0 \\
\hline 10 & Eastern & 100 & 141.7 & 180.4 & -2.8 & -2.1 & 15.0 & 16.5 & 315.8 & 366.9 \\
\hline \multicolumn{2}{|c|}{ Average eastern } & 93.3 & 179.9 & 223.1 & -3.1 & -2.3 & 14.7 & 16.3 & 313.6 & 349.0 \\
\hline \multicolumn{2}{|c|}{ Total average } & 87.1 & 204.0 & 222.2 & -2.3 & -1.3 & 14.6 & 16.0 & 315.5 & 337.5 \\
\hline
\end{tabular}


10). The overall proportion of Scots pine individuals where Lophodermium spp. were detected was $87.1 \%$ (Table 2).

Objects were divided into two groups (eastern and western region) to find the regional differences between detection of Lophodermium spp. Lophodermium spp. were more frequent in the eastern region ( $\mathrm{p}=0.004)$ (Fig. 4). Differences in occurrence of Lophodermium spp. in young stands of Scots pine in eastern and western regions could be explained by differences in meteorological (e.g. temperature and precipitation) conditions in the previous year (autumn and winter temperature) and during the survey year during Lophodermium spp. development from May to August.

A previous study (Moročko-Bičevska et al., 2010) had surveyed the occurrence of Lophodermium spp. in Latvian pine stands using a fungal culturing method. Samples for this study were collected in 2009, and the current samples were collected in similar locations, in order to enable the comparison of meteorological data. In 2016, using PCR detection, Lophodermium spp. were found in $87.1 \%$ of analyzed needle samples. The occurrence data were obtained using different approaches (cultivation on media in 2009 and PCR detection in 2016), however, the occurrence of Lophodermium spp. was lower in 2009. A significant difference in occurrence between the eastern and western regions was found in 2016. Based on the fact that autumn and winter meteorological weather conditions of the previous year affect the development of Lophodermium spp. in the next year (Drenkhan, 2011), it was concluded that in 2015 winter was warmer $\left(-1.3 \pm 0.8^{\circ} \mathrm{C}\right)$ than in $2008\left(-2.3 \pm 0.3{ }^{\circ} \mathrm{C}\right)$, and the amount of precipitation in autumn of 2015 was higher $(222.2 \pm 2.7 \mathrm{~mm})$ compared to the amount of precipitation in year $2008(204.0 \pm 5.9 \mathrm{~mm})$. The autumn precipitation in 2015 was similar between the western and eastern regions $(221.4 \mathrm{~mm}$ and 223.1 $\mathrm{mm}$ ), and the average winter temperatures were lower in the eastern region (Table 2). However, the average precipitation in May-August 2016 was higher in the eastern region, and the average temperature in MayAugust 2016 was also slightly higher in the eastern region. These differences in May-August precipitation and temperature were not as pronounced in 2009 (when no significant differences in occurrence of Lophodermium spp. were found between the eastern and western regions).

Air temperature and precipitation during the time of Lophodermium spp. development (from May to August) in 2009 was $14.6 \pm 0.2{ }^{\circ} \mathrm{C}$ and the amount of precipitation was less than $315.5 \pm 6.2$ $\mathrm{mm}$, but temperature in 2016 was $16.0 \pm 0.3{ }^{\circ} \mathrm{C}$ and precipitation was $337.5 \pm 6.5 \mathrm{~mm}$. The previously mentioned differences between the analyzed years were statistically significant $(p<0.001)$. When analyzing air temperature and precipitation differences between eastern and western regions in 2009 and 2016, the differences during the period from May to August are small, but could affect the development of Lophodermium spp. Air temperature in eastern region in 2009 was $14.7 \pm 0.5{ }^{\circ} \mathrm{C}$, the amount of precipitation was $313.6 \pm 9.0 \mathrm{~mm}$, but in western region air temperature was $14.5 \pm 0.6{ }^{\circ} \mathrm{C}$, the amount of precipitation was $317.3 \pm 10.5 \mathrm{~mm}$. In 2016, the air temperature in eastern region was $16.3 \pm 0.3{ }^{\circ} \mathrm{C}$ and amount of precipitation was $349.0 \pm 13.8 \mathrm{~mm}$, but in western region it was $15.7 \pm 0.4^{\circ} \mathrm{C}$ and $326.0 \pm 4.5 \mathrm{~mm}$, respectively. In several other studies - temperature and precipitation were mentioned as some of the main factors for the occurrence, development and spread of needlecast (Drenkhan, 2011; Rajkovic, Markovic, \& Rakonjac, 2013). Researchers in their studies have found that the fungus is capable of sporulation and its spores germinate in any time during the year

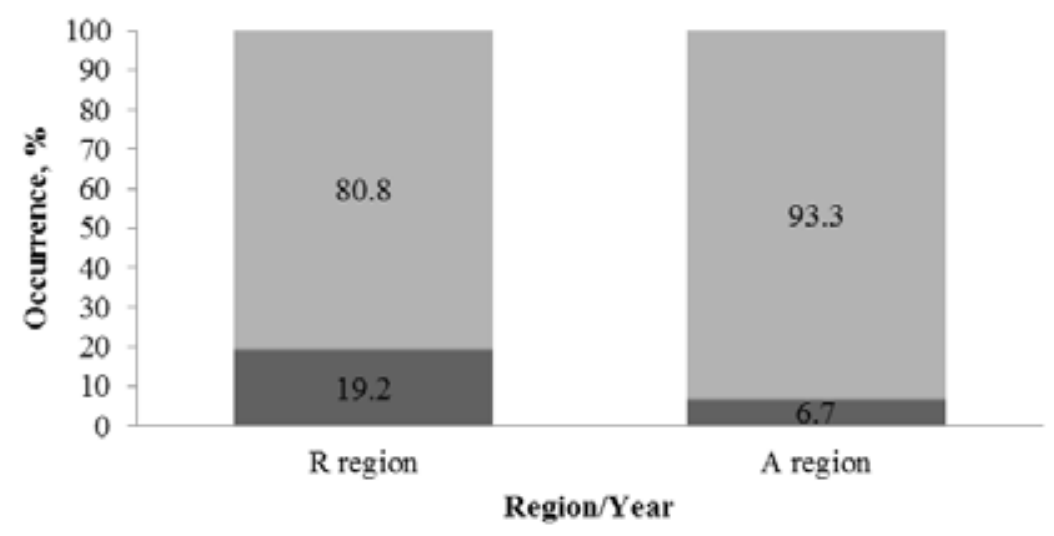

= Detected

Not detected

Figure 4. Occurrence of Lophodermium spp. in eastern and western regions. 
when air temperature is above $+5{ }^{\circ} \mathrm{C}$ and there is enough moisture (Thyr \& Shaw, 1964). The optimum temperature for the development of ascospores (including Lophodermium spp.) is from $+14{ }^{\circ} \mathrm{C}$ to $+22{ }^{\circ} \mathrm{C}$, minimum temperature is from -2 to $+1{ }^{\circ} \mathrm{C}$, with a maximum from $+25{ }^{\circ} \mathrm{C}$ to $+35{ }^{\circ} \mathrm{C}$ (Karadžić \& Milijašević, 2008; Peterson, 1967; Gadgil, 1974). In the study, Lophodermium spp. in majority of cases have been observed directly on the previous year's needles, and in some cases also on the current year's needles. This shows that the degree of Lophodermium spp. infection significantly affects the current year's height increase of a tree and tree growth potential, and it is also noted by other scientists (Staley \& Nicholls, 1989; Kanaskie, 1990). Needlecast primarily damages the current year (autumn infected) needles, which have a greater role in ensuring the growth of tree overground parts than older needles (Drenkhan, Kurkela, \& Hanso, 2006). Martinsson (1979) found a significant negative correlation $(\mathrm{r}=-0.80, \alpha=$ 0.01 ) between the current year's relative increase of tree length and needle loss determined by needlecast infection degree. A similar correlation was found by other researchers (Baumanis, 1975; Squillace, La Bastide, \& Van Vredenburch, 1975).

The two surveys of the occurrence of Lophodermium spp. in young Scots pine stands (MoročkoBičevska et al., 2010, and this report) in Latvia utilized different methods for fungal detection (culturing vs PCR). In both cases, although only needles showing needlecast symptoms were collected for analysis, Lophodermium spp. were not detected in all samples. It is not clear, if this is due to technical limitations of the utilized detection techniques leading to false negatives, or additional, undetected pathogens could be inducing similar symptoms. In addition, the differences in occurrence frequency between the two reports may be due to differences between the detection techniques utilized. Therefore, additional studies are needed to obtain more accurate data about correlations between Lophodermium spp. occurrence and meteorological weather conditions in eastern and western regions, as well as throughout the entire territory of Latvia.

\section{Conclusions}

1. The presence of Lophodermium spp. was detected in all surveyed stands, and occurrence differences between the western and eastern regions were significant $(\mathrm{p}=0.004)$.

2. The occurrence of Lophodermium spp. in the eastern and western region was affected by the previous year's autumn and winter meteorological weather conditions and differences in the given years' air temperature and precipitation.

3. In 2016, the eastern region of Latvia had a higher May-August precipitation and, to a lesser extent, temperature, which correlated with a higher occurrence of Lophodermium spp.

\section{Acknowledgements}

The study was supported project 'Forest management risks: prognosis and minimization'. We thank Kristine Kenigsvalde for valuable suggestions, Janis Ivanovs for mathematical calculations of data and Elza Rauda for the help in sampling.

\section{References}

1. Adamson, K., Klavina, D., Drenkhan, R., Gaitnieks, T., \& Hanso, M. (2015). Diplodia sapinea is colonizing the native Scots pine (Pinus sylvestris) in the northern Baltics. European Journal of Plant Pathology, 143(2), 343 - 350. DOI: 10.1007/s10658-015-0686-8.

2. Arhipova, I., \& Bāliņa, S. (2003). Statistika ekonomikā. Risinājumi ar SPSS un Microsoft Excel. (Statistics economy. Solutions with SPSS and Microsoft Excel). Rìga: Datorzinības Centrs. (in Latvian).

3. Baumanis, I. (1975). Priežu pēcnācēju rezistence pret skujbiri un tās korelācija ar citām pazīmēm. (Pine progeny resistance to needlecast, and its correlation with other features). Jaunākais Mežsaimniecībāa, 17, 28. - 32. lpp. (in Latvian).

4. Booy, G., Hendriks, R.J.J., Smulders, M.J.M., Van Groenendael, J.M., \& Vosman, B. (2000). Genetic Diversity and the Survival of Populations. Plant biology, 2(4), 379 - 395, DOI: 10.1055/s-2000-5958.

5. Diwani, A.S., \& Millar, S.C. (1990). Sources of inoculum of Lophodermium seditiosum on Pinus sylvestris. European Journal of Plant Pathology, 20, 1 - 7.

6. Doyle, J.J., \& Doyle, J.L. (1987). A rapid DNA isolation procedure for small quantities of fresh leaf tissue. Phytochemical Bulletin, 19, $11-15$.

7. Drenkhan, R., Kurkela, T., \& Hanso, M. (2006). The relationship between the needle age and the growth rate in Scots pine (Pinus sylvestris): a retrospective analysis by needle trace method (NTM). European Journal of Forest Research, 125, 397 - 405. DOI: 10.1007/s10342-006-0131-9.

8. Drenkhan, R. (2011). Epidemiological investigation of pine foliage diseases by the use of the needle traces method. Unpublished doctoral dissertation, Estonian University of Life Sciences, Tartu, Estonia.

9. Edenhofer, O., Pichs-Madruga, R., Sokona, Y., Farahani, E., Kadner, S., Seyboth, K., ... Minx, J.C. (eds.). (2014). IPCC, Climate Change (2014): Mitigation of Climate Change. Contribution of Working Group III 
to the Fifth Assessment Report of the Intergovernmental Panel on Climate Change. Cambridge University Press, Cambridge, United Kingdom and New York, NY, USA.

10. Gadgil, P.D. (1974). Effect of temperature and leaf wetness period on infection of Pinus radiate by Dothistroma pini. New Zealand Journal of Forestry Science, 4, 495 - 501.

11. Hanso, M., \& Drenkhan, R. (2007). Retrospective analysis of Lophodermium seditiosum epidemics in Estonia. Acta Silvatica Lignaria Hungarica, Special Edition, 31 - 45.

12. Jansons, $\bar{A}$. (2008). Genotype-environment interaction in Latvian Scots pine growth and quality traits and its impact to progeny testing. In Research for Rural Development 2008: International Scientific Conference Proceedings, 21 - 23 May 2008 (pp. 128 - 136). Jelgava, Latvia: Latvia University of Agriculture.

13. Jansons, A.., Baumanis, I., Dreimanis, A., \& Gailis, A. (2006). Variability and genetic determination of Scots pine quantitative traits at the age of 32 years. In Research for Rural Development 2006: International Scientific Conference Proceedings, 17 - 20 May 2006 (pp. 289 - 295). Jelgava, Latvia: Latvia University of Agriculture.

14. Jansons, Ā., Donis, J., Danusevičius, D., \& Baumanis, I. (2015b). Differential analysis for next breeding cycle for Norway spruce in Latvia. Baltic Forestry 21(2), 285 - 297.

15. Jansons, A., Matisons, R., Baumanis, I., \& Purina, L. (2013a). Effect of climatic factors on height increment of Scots pine in experimental plantation in Kalsnava, Latvia. Forest Ecology and Management, 306, 185 $-191$.

16. Jansons, A., Matisons, R., Libiete-Zālīte, Z., Baders, E., \& Rieksts-Riekstiņš, J. (2013b). Relationships of height growth of lodgepole pine (Pinus contorta var. latifolia) and Scots pine (Pinus sylvestris) with climatic factors in Zvirgzde, Latvia. Baltic Forestry, 19(2), 236 - 244.

17. Jansons, Ā., Matisons, R., Zadiņa, M., Sisenis, L., \& Jansons, J. (2015a). The effect of climatic factors on height increment of Scots pine in sites differing by continentality in Latvia. Silva Fennica, 49(3), id 1262. 14p. DOI: $10.14214 / \mathrm{sf} .1262$.

18. Jansons, Ā., Matisons, R., Šēnhofa, S., Katrevičs, J., \& Jansons, J. (2016b) High-frequency variation of tree-ring width of some native and alien tree species in Latvia during the period $1965-2009$. Dendrochronologia, 40, 151 - 158.

19. Jansons, A., Neimane, U., Dzerina, B., \& Adamovics, A. (2016a). Influence of lammas shoots on height of young Scots pines in Latvia. Agronomy research, 14(2), 407 - 417.

20. Kanaskie, A. (1990). Lophodermium Needle Cast of Scotch Pine. In: P.B. Hamm, S.J. Campbell, E.M. Hansen (eds.) Growing Healthy Seedlings: Identification and management of pests in northwest forest nurseries. Oregon State University, Oregon, USA, pp. 34.

21. Karadžić, D., \& Milijašević, T. (2008). The most important parasitic and saprophytic fungi in austrian pine and scots pine plantations in serbia. Bulletin of the Faculty of Forestry, 97, 147 - 170.

22. Kḷaviņa, D., Ķiesnere, R.D., Korica, A.M., Arhipova, N., Daugavietis, M., \& Gaitnieks, T. (2012). Skuju koku mizas ekstraktu ietekmes uz Lophodermium seditiosum micēlija attīstību in vitro novērtējums. (Evaluation of impact of pine bark extracts on mycelial growth of Lophodermium seditiosum in vitro). Mežzinātne, 26(59), 167. - 181. lpp. (in Latvian).

23. Liesebach, M., \& Stephan, B.R. (1996). Results of the IUFRO 1982 Scots pine (Pinus sylvestris L.) provenance experiment in southwestern Germany. Silvae Genetica, 45, 342 - 349.

24. Martinsson, O. (1979). Testing Scots pine for resistance to Lophodermium needle cast. Studia Forestalia Suecica, 150, $63 \mathrm{p}$.

25. Millar, C. (1975). Report on 5th European colloquium for forest pathologists - Lophodermium in pines. European Journal of Forest Pathology, 5(6), 383 - 384. DOI: 10.1111/j.1439-0329.1975.tb00496.x.

26. Moročko-Bičevska, I., Fatehi, J., Baumanis, I., \& Veinberga, I. (2010). Study of brown needle cast disease of Pinus sylvestris in Latvia. International Mycology Congress, 1 - 7 August 2010, Edinburg, UK.

27. Ormrod, D.J. (1976). Control of Lophodermium needle cast of Scots pine Christmas trees in British Columbia. Canadian Plant Disease Survey, 56, 69 - 72.

28. Ortiz-García, S., Gernandt, D.S., Stone, J.K., Johnston, P.R., Chapela, I.H., Salas-Lizana, R., \& AlvarezBuylla, E.R. (2003). Phylogenetics of Lophodermium from pine. Mycologia, 95(5), 846 - 859.

29. Peterson, G.W. (1967). Dothistroma needle blight of Austrian and ponderosa pines: epidemiology and control. Phytopathology, 57, $437-441$.

30. Rajkovic, S., Markovic, M., \& Rakonjac, L. (2013). Incubation Methods for Forecasting the Occurrence and Development of Lophodermium seditiosum Minter, Staley \& Millar on Pine. In: Mizuho Nita (ed.) Fungicides - Showcases of Integrated Plant Disease Management from Around the World, ISBN 978-95351-1130-6, DOI: 10.5772/51233. 
31. Reich, P.B., Wright, I.J., Cavender-Bares, J., Craine, J.M., Oleksyn, J., Westoby, M., \& Walters, M.B. (2003). The Evolution of Plant Functional Variation: Traits, Spectra, and Strategies. International Journal of Plant Sciences, 164(3), 143 - 164.

32. Rieksts-Riekstins, J., Jansons, A., Smilga, J., Baumanis, I., Ray, D., \& Connolly, T. (2014). Climate suitability effect on tree growth and survival for Scots pine provenances in Latvia. In Research for Rural Development 20014: International Scientific Conference Proceedings, 21 - 23 May 2014 (pp. 57 - 62). Jelgava, Latvia: Latvia University of Agriculture.

33. Squillace, A.E., La Bastide, J.G.A., \& Van Vredenburch, C.L.H. (1975). Genetic variation and breeding of Scots pine in the Netherlands. Forest Science, 21(4), $341-352$.

34. Staley, J.M., \& Nicholls, T.H. (1989). Lophodermium Needle Cast. In: Cordell CE, Anderson RL, Hoffard WH, Landis TD, Smith RSJr, Toko HV (eds.). Forest Nursery Pests. USDA Forest Service, Agriculture Handbook, (680, pp. $49-51)$.

35. Stenström, E., \& Arvidsson, B. (2001). Fungicidal control of Lophodermium seditiosum on Pinus sylvestris seedlings in Swedish forest nurseries. Scandinavian Journal of Forest Research, 16, 147 - 154. DOI: $10.1080 / 028275801300088224$.

36. Stenström, E., \& Ihrmark, K. (2005). Identification of Lophodermium seditiosum and L. pinastri in Swedish forest nurseries using species-specific PCR primers from the ribosomal ITS region. Forest pathology, $35(3), 163-172$.

37. Thyr, B.D., \& Shaw, C.G. (1964). Identity of the fungus causing red band disease on pines. Mycologia, 56(1), 103 - 109. DOI: 10.2307/3756402. 